\title{
THE EFFECTIVENESS OF CLOPIDOGREL AS AN ANTITHROMBOTIC COMPARED TO TICLOPIDINE AND ASPIRIN (META-ANALYSIS)
}

\section{EFEKTIVITAS CLOPIDOGREL SEBAGAI ANTITROMBOTIK DIBANDINGKAN TERHADAP TICLOPIDINE DAN ASPIRIN (META-ANALYSIS)}

\author{
Titien Siwi Hartayu*), Dewi Setyaningsih \\ Fakultas Farmasi, Universitas Sanata Dharma, Kampus III Maguwoharjo Depok Sleman, \\ Yogyakarta 55282, Indonesia
}

Received October 21, 2016; Accepted March 30, 2017

\begin{abstract}
Clopidogrel, an antithrombotic drug, has been proven by FDA as Plavix® was initially used for the prevention of vascular occlusive that cause of myocardial infarction, stroke, and vascular death in patients with atherosclerosis and then it is used to treat Acute Coronary Syndrome (ACS). Aim of the study is to compare the effectiveness of Clopidogrel to aspirin and ticlopidine by meta-analysis of CLASSICS (The Clopidogrel Aspirin Stent International Cooperative Study), MATCH trial dan CAPRIE trial. Results of the study show that the effectiveness of Clopidogrel is significantly higher, however the risk of ischemic and bleeding is lower than aspirin and ticlopidine. Cost-effectiveness of Clopidogrel in avoiding secondary stroke in one episode is approximately US \$33,000, and aspirin is only US \$1400. In Indonesia the price of Clopidogrel is ranged from US \$1.5 to US \$3 each tablet, while the price of aspirin ranged from US \$0.35 to US \$ 0.72. However, in Indonesia Clopidogrel is now in the list of National Formulary, this fact might have contributed to the increasing use of Clopidogrel, which has reached around 1000 tablets per day in each hospital while aspirin has reached almost 1500 tablets per day.
\end{abstract}

Keywords: antithrombotic, aspirin, antiplatelet, Clopidogrel, ticlopidine

\begin{abstract}
ABSTRAK
Clopidogrel sudah mendapat ijin edar dari FDA sejak November 1998 dengan nama Plafiks ${ }^{\circledR}$ dan digunakan untuk pencegahan vascular oclusive yang dapat menimbulkan myocard infarction dan stroke. Selanjutnya, Clopidogrel diindikasikan untuk pengatasan Acute Coronary Syndrom (ACS). Studi ini ditujukan untuk membandingkan efektifitas Clopidogrel dengan ticlopidine dan aspirin sebagai antithrombotik melalui meta-analisis, yaitu CLASSICS (The Clopidogrel Aspirin Stent International Cooperative Study), MATCH trial dan CAPRIE trial. Hasil studi menunjukkan bahwa Clopidogrel lebih efektif secara signifikan dibandingkan dengan aspirin $(5,32 \%$ vs $5,87 \%)$, dan risiko terjadinya serangan Ischemia dan perdarahan lebih rendah dibandingkan dengan aspirin dan ticlopidine. Biaya pencegahan terjadinya serangan stroke yang ke-dua dengan menggunakan Clopidogrel diperkirakan mencapai US \$ 33,000 , sedangkan pada penggunaan aspirin hanya sekitar US \$ 1400. Sementara di Indonesia harga Clopidogrel berkisar mulai dari US \$ 1.5 sampai US \$ 3 per tablet, 2 kali lipat harga aspirin yang hanya berkisar antara US \$ 0.35 sampai US \$ 0, 72. Namun demikian di Indonesia Clopidogrel saat ini juga sudah dimasukkan ke dalam Fornas. Kemungkinan hal inilah yang menyebabkan penggunaan Clopidogrel di Indonesia mulai meningkat, dengan penggunaan rata-rata per Rumah Sakit mencapai 1000 tablet per hari, dan aspirin lebih dari 1500 tablet per hari.
\end{abstract}

Kata kunci: antitrombotik, aspirin, antiplatelet, Clopidogrel, ticlopidine

*Corresponding author: Titien Siwi Hartayu

Email: titien@usd.ac.id 


\section{INTRODUCTION}

Clopidogrel, an antithrombotic drug, was approved by FDA to the market since November 17, 1998. First approved by FDA, Clopidogrel known as Plavix ${ }^{\circledR}$ was initially used merely for the secondary prevention of vascular occlusive events that renders to the event of myocardial infarction, stroke, and vascular death in patients with atherosclerosis documented by recent stroke, recent myocardial infarction, or established peripheral arterial disease. In August 2001, Clopidogrel was used in unstable angina to prevent recurrent events for preventing of re-current vascular occlusive problem, and then in September 2002, Clopidogrel has gained new indication for non-ST-segment elevation Acute Coronary Syndrome (ACS) (NHS, 2004).

ACS is a set of signs and symptoms suggestive of sudden cardiac ischemia, usually caused by such event of eroded and ruptured atherosclerotic plaque as the results of sequential events involving platelet adhesion, activation and subsequent aggregation that can lead to vascular occlusion in an epicardial coronary artery. This evidence is also called as arterial thrombosis. The acute coronary syndromes include Unstable Angina (UA), Non-ST Segment Elevation Myocardial Infarction (NSTEMI), and ST Segment Elevation Myocardial Infarction (STEMI), commonly referred to as a heart attack. (Yeghiazarians, Braunstein, Askari, \& Stone, 2000)

The patophysiology of ACS relies on the role of platelet activation. Normally, platelets do not interact with the endothelium of healthy vessels; however, as a result of inflammation cascades, platelets adhere to exposed subendothelial structure in damaged vessels. This action subsequently triggers a cycle of recruitment and adhesion of additional platelets and results in the expression and assembly of receptor for fibrinogen on the platelet surface. This receptor, the platelet glycoprotein (GP) IIb/IIIa receptor is the final common pathway for platelet aggregation as it binds to bivalent fibrinogen molecules to form platelet aggregates. Stable platelet aggregation is augmented by two autocrine factors genereated upon platelet stimulation: Adenosine diphosphate (ADP), release from platelet dense bodies, and TXA2 generated by sequential action of Cox -1 and thromboxane synthase on the arachidonic acid released from membrane phospholipids (Philips, Conley, Sinha, \& Andre, 2005; Sharis, Cannon, \& Loscalzo, 1998; Weitz \& Hirsh, 1998).

Clopidogrel, a member of thienopyridines, is an antiplatelet agent by first aid of cytochrom P450 (CYP) activation, and accordingly its active metabolite drug acts as a selective inhibitor for adenosine diphosphate (ADP)-induced platelet aggregation and thereby affecting ADP-dependent activation of the glycoprotein GPIIb/IIIa complex (Figure 1), the major receptor for fibrinogen present on the platelet surface. Therefore, platelet aggregation can be prevented. Aspirin, another antithrombotic agent, acts in different way with Clopidogrel or ticlopidine as aspirin prevent thrombotic event via blocking thromboxane A2dependent platelet recruitment (Weitz and Hirsh, 1998). Combination of Clopidogrel and aspirin showed synergistic effect in studies using models of thrombosis (Harker et al., 1998; Herbert et al., 1998).

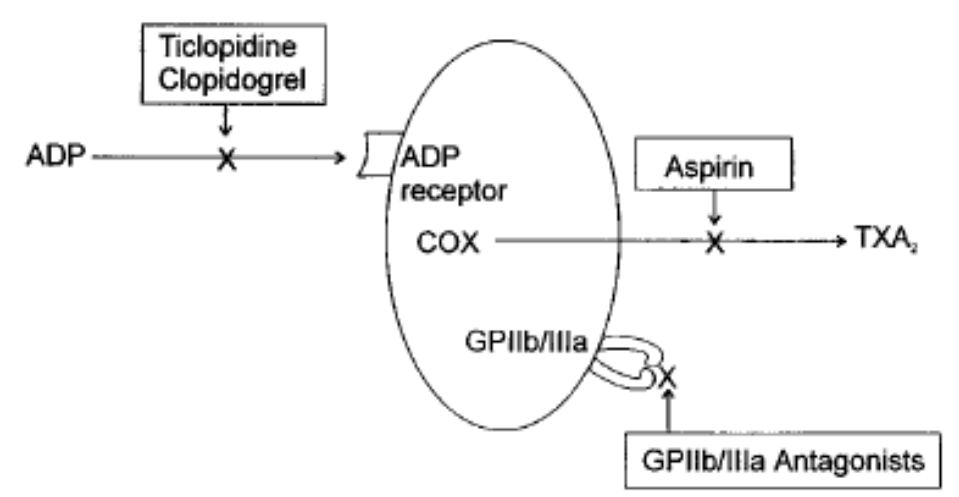

Figure 1. Selective blockage platelet activation by Clopidogrel, aspirin and GPIIb/IIIa antagonists (Weitz \& Hirsh, 1998) 


\section{THE RATIONAL PATHWAY OF DRUG DISCOVERY APPLIES ON THE DEVELOPMENT OF CLOPIDOGREL}

Based on the understanding of the patophysiological pathway of atherothrombosis event and antagonism activity on preventing thrombotic event, Clopidogrel, was developed by chemical modifying of previously found drug ticlopidine, an antagonist of ADP receptor (Bhatt, Bertrand, Berger, 2002; Sado, 2001). Moreover, since ticlopidine, the drug that exist before shows remarkable side effect of causing neutropenia, Clopidogrel was discovered for the aim of a better drug effect with lower toxicity.

There were found abundant information about the effectiveness and safety of Clopidogrel over the previous found drug ticlopidine. In animal study, modelled for thrombosis, Clopidogrel showed its higher activity compared to ticlopidine (Herbert, Tissinier, Defreyn, Maffrand, 1993). Compared with the preceding antihrombotic agent, ticlopidine, the safety and tolerability of Clopidogrel showed superior to ticlopidine in CLASSICS (The Clopidogrel Aspirin Stent International Cooperative Study) (Bertrand, Rupprecht, Urban, Gershlick, 2000).Based on these abundant research in safety and effectiveness of Clopidogrel, Sanofi-Syntelabo applied for its approval to FDA.

\section{EFFECTIVENESS AND SAFETY STUDIES AND META-ANALYSIS}

The efficacy of Clopidogrel was weighed by evaluating its effect on reducing the composite primary endpoint of atherethrombotic event from Clopidogrel compared to aspirin in CAPRIE studies (Committee, 1996). This randomized, blinded study, involved 19,185 patients with a high risk of atherothrombotic event, from 384 centres in 16 different countries. These patients were assigned in 3 years study and divided into two group, one group was treated with $75 \mathrm{mg}$ daily of Clopidogrel while another one were $325 \mathrm{mg}$ of aspirin. The outcome was set on composite endpoints, which are vascular death, myocardial infarction (MI), and or ischaemic stroke. Effectiveness of Clopidogrel is slightly but significantly higher than aspirin as proven in this report that treatment with Clopidogrel showed the primary endpoint $5.32 \%$ vs $5.87 \%$ with aspirin. This report also suggested the overall risk reduction of $8.7 \%$ (95\% CI $0.3,16.5$; $\mathrm{P}=0.043$ ) by Clopidogrel. The effectiveness of Clopidogrel was also confirmed by reducing the total number of hospitalizations for ischemic events and bleeding in Clopidogrel compared with aspirin over an average of 1.6 years of treatment.

Despite the slightly higher in the effectiveness of Clopidogrel compared to aspirin in CAPRIE study targeted for patient suffered from high risk of atherothrombotic event, there were reported evidence that the more significant benefit of Clopidogrel is favorable seen in patients enrolled in CAPRIE with pre-existing symptomatic atherothrombotic disease or additional risk factors such as diabetes mellitus and hypercholesterolaemia. In these sub-groups of CAPRIE trial, 4,496 patients had previously suffered an ischaemic stroke and MI, and were a substantially elevated risk of atherothrombotic events, resulted in primary endpoint of $8.8 \%$ in Clopidogrel group compared to $10.2 \%$ in the aspirin treated group (Ringleb, Bhatt, Hirsch, 2004). Moreover, the beneficial effect of Clopidogrel was amplified by the result of a relative risk reduction of Clopidogrel over aspirin of $14.9 \%$ (95\% CI 0.3, 27.3; $\mathrm{P}=0.045)$ and absolute risk reduction of $3.4 \%$ (34 events avoided per 1000 patients per year among the 19,825 patients enrolled CAPRIE per 2 years (Durand-Zaleski and Bertrand, 2004).

The beneficial effect of Clopidogrel was also observed from CAPRIE study assigned for the group with diabetic pre-existing disease. The annual event rate for the composite endpoint of vascular death, MI, stroke or re-hospitalization for ischaemia or bleeding was $15.6 \%$ in the Clopidogrel group and $17.7 \%$ in the aspirin group. The advantage of Clopidogrel treatment versus aspirin 
confirmed by the report of relative risk reduction of $13.1 \%$ favorable to Clopidogrel (95\% CI 1.2, 23.7; $\mathrm{P}=0.032$ ). Moreover, the absolute risk reduction in patient with diabetic history was $21 \%$ for Clopidogrel versus $11 \%$ for aspirin therapy (Bhatt, Marso, Hirsch, 2002).

In the safety study in CAPRIE, there was evidence that Clopidogrel was also associated with lower risk of bleeding complications compared with aspirin as demonstrated by lower gastrointestinal haemorrhage ( 1.99 vs $2.66 \% \mathrm{P}<0.05)$ and trend towards a lower incidence of intracranial haemorrhage $(0.33$ vs $0.47 \% \quad \mathrm{P}=0.23)$ (Committee, 1996). Furthermore the safety of clopidogrel was reported superior than the precedence antiplatelet agent ticlopidine. Clopidogrel did not cause the severe hematologic side effect compared to ticlopidine (Steinhubl, Tan, Foody, Topol, 1999). Additionally, Clopidogrel is better tolerated than aspirin, since the onset of action is more rapid and the once-a-day dosing regiment is more convenient (Bhatt, Bertrand, Berger, 2002).

Comparison in safety and efficacy study also assigned for Clopidogrel and ticlopidine in meta analysis of randomized and registry of ticlopidine with Clopidogrel after stenting (Bhatt, Bertrand, Berger, 2002). The research which involved almost 14,000 patients showed the efficacy of Clopidogrel is superior to ticlopidine. The author suggested that this is due to better patient compliance to Clopidogrel as demonstrated in the randomized CLASSIC data (Bertrand, Rupprecht, Urban, Gershlick, 2000). From the hematologic profile of Clopidogrel compared to ticlopidine, it was fortified that possibility of long-term therapy with Clopidogrel is more acceptable than long-term ticlopidine therapy (Bhatt, Bertrand, Berger, 2002).

Combination of Clopidogrel and low dose of aspirin is recently being the favorable standard antiplatelet therapy, replacing the dual combination aspirin and ticlopidine. This new strategy is supported by a large amount pre-clinical and clinical research on the efficacy and safety of Clopidogrel over ticlopidine. A pre-clinical study showed that co-therapy of aspirin with Clopidogrel set with loading dose and daily dose, reduce significantly graft and stent thrombosis event. Synergisms between aspirin and Clopidogrel was also demonstrated by Makkar et al in ex vivo study (Makkar et al., 1998). Clinical study fase III in CURE study confirmed the benefit of dual combination Clopidogrel and Aspirin. In this study that involved 12,562 patients with acute coronary syndrome without ST-segment elevation, combination Plavix (Clopidogrel)-aspirin showed the reduction in the number of patient experiencing the primary endpoint (CV death, MI, or stroke). In the plavix treated group $9.3 \%$ patients experienced the primary endpoint compared to $11.41 \%$ in those plavix untreated group. Moreover, at the end of 12 months, the coprimary outcome $(\mathrm{CV}, \mathrm{MI}$, stroke or refractory ischemia was $16.54 \%$ in the plavix-treated group and $18.83 \%$ in aspirin treated group.

\section{NEW INDICATION FOR CLOPIDOGREL}

Previously, Clopidogrel was indicated for the reduction of atheroschlerotic events including myocardial infarction, stroke, or peripheral artery disease, and is used in patients with non-ST segment elevation acute coronary syndrome for those who are going to be medically managed or to receive percutaneous coronary intervention (Aschenbrenner and Price, 2007).

New indication of Clopidogrel appears as the results from the trial of Unstable angina to prevent Recurrent Event (CURE) led to FDA approval to the new indication that includes indication for the prevention of thrombotic events in patients who had myocardial infarction with acute ST-segment elevation and are not going to have coronary artery stenting (Aschenbrenner and Price, 2007). According to this setting, a loading dose of $300 \mathrm{mg}$ followed by $75 \mathrm{mg}$ daily should be used.

\section{IMPACT OF DRUG IN THERAPY}

In the therapy of using antiplatelet drug administered orally, aspirin is the first-line 
antiplatelet therapy for patients with STsegment elevation myocardial infarction (MI) (Diener, 2002; Donnan and Davis, 2002; Tran and Anand, 2004; Warlow, 2002). This is because from the calculation of costeffectiveness there no other antiplatelet drug is superior compared to aspirin. From the data presented by Garattini S and Bertele V, monthly cost for secondary prevention of cardiocasvular event, the cost is $€ 2.3$; €14.0; $€ 70.0$ for aspirin, ticlopidine, and Clopidogrel respectively (Garattini and Bertele, 2004). For the patients who are showing their intolerance with aspirin, then Clopidogrel is given in the substitution of aspirin. In the second line of therapy is the combination of aspirin plus Clopidogrel for patients with recurrent acute coronary syndrome. However, in the MATCH trial, a trial to study the combination therapy of aspirin and Clopidogrel in term of the safety and efficacy in the patient with stroke disease, showed that the combination therapy of aspirin and Clopidogrel non-significantly reduces the relative risk of the primary endpoint which are myocardial infarction, ischemic stroke, and vascular death. Moreover, in the safety point, there was significantly increased in life-threatening bleeding for the combination therapy of Clopidogrel and aspirin (Amarenco and Donnan, 2004).

The use of Clopidogrel in patient suffer from ACS disease is in the alternative agent as the first treatment the doctors are still choose for aspirin. Only for the patient who has gastrointestinal intolerance to aspirin and with an allergy to aspirin, Clopidogrel is the drug of choice in the treatment of ACS (Braunwald, Antman, Beasly, 2002).

\section{HEAD TO HEAD COMPARISON}

A large trial carried in CAPRIE clinical studies provides the head to head comparison between Clopidgrel and aspirin in the prevention of recurrent of ischemic events in patients at high risk of ischemia events (acute myocardial infarction (AMI), stroke, symptomatic peripheral arterial disease). The primary end point was the combination in prevention of MI, ischemic stroke, or vascular death. Clopidogrel significantly reduced the relative risk of the primary endpoint by $8.7 \%$ (Commitee, 1996). Contrary to the result of superiority Clopidogrel over aspirin, significant benefit of Clopidogrel is no longer established when statistical calculation is made in separated index event. In preventing the recurrent of AMI, and stroke, the advantage of Clopidogrel is much smaller and is not significantly different with aspirin treatment group. The greater significant benefit of Clopidogrel is obtained in the group with peripheral arterial disease. Therefore, the significant benefit of Clopidogrel is driven by peripheral arterial disease group (Gebel, 2005; Hankey, 2005).

Comparative study between Clopidogrel and aspirin is thought to be less rational since the aim of developing Clopidogrel was to discover a better and less toxic drug than ticlopidine. Although a meta-analysis study in comparison of Clopidogrel and ticlopidine after stenting was available (D. L. Bhatt, Bertrand, Berger, 2002), it gain critics that the study was performed in too short time for observation of primary endpoint (30 days) (Garattini and Bertele, 2004).

Another randomized comparison study of Clopidogrel and triclopidin in their combination with aspirin for 28 months showed that a higher mortality was found in the Clopidogrel group instead of triclopidie (Mueller et al., 2003). However in CAPRIE trial, neutropenia as observed in ticlopidine side effect, was less in Clopidogrel and aspirin ( $0,10 \%$ for Clopidogrel and $0.17 \%$ in aspirin) (Commitee, 1996).

\section{REIMBURSEMENT}

Effectiveness studies on comparison of Clopidogrel and the standard therapy, aspirin in CAPRIE trial showed that although Clopidogrel significantly attenuated platelet induced aggregation, however, the beneficial effect of Clopidogrel over aspirin is considerably modest. Therefore additional benefit is likely statistically and the drug has not been granted a claim of superiority over aspirin by the regulatory authorities. In the CAPRIE trial which compared Clopidogrel 
versus aspirin, there was a significantly reducing for stroke, MI or vascular death in favour of Clopidogrel (in approximately $8 \% \mathrm{p}$ $=0.03)$. However, one publication reported that the CAPRIE trial was not powered to detect treatment differences within patient subgroups. Moreover, based on the statistical analyses, it was revealed a significant patient heterogeneity with respect to the results for the various subgroups in CAPRIE trial $(\mathrm{p}=0.042)$. When patients from the stroke and peripheral arterial disease (PAD) were pooled out, the results favored Clopidogrel. However, it is noticed that the proportion of patient with PAD is much bigger than that of stroke. Therefore the conclusion in comparison of Clopidogrel and aspirin in secondary prevention of cardiovascular disease was driven by disproportionality of group with PAD reflects the conclusion. Apparently when the results for subgroups were compared, there was no significant difference between Clopidogrel and ASA in patients with stroke or MI (Gebel, 2005).

Three years after the approval of Clopidogrel by FDA, the Netherlands government decided to put Clopidogrel in the list of drug reimbursement. Regulation of reimbursement of Clopidogrel in Netherlands was released in 26 of July 2000 (Algra and Gijn, 2000). The official indication for Clopidogrel is secondary prevention in patients with atherosclerotic disease and proven to be aspirin sensitive. However, even though many publication recommend the use of Clopidogrel in one-year treatment to reduce ACS, Netherlands government allowed for its reimbursement only for 6-months therapy with Clopidogrel. There are three principle criteria in establishing a decision for reimbursement of drug, i.e., therapeutic benefit, costeffectiveness evidence, and burden of disease.

This strict reimbursement policy of allowing only 6-month therapy with Clopidogrel is supported by the study on the calculation of cost-effectiveness in stroke management on Clopidogrel. A study by Niessen et. al. revealed that using acetylsalycilic acid was more cost-effective compared to Clopidogrel (Niessen, Dippel,
Limburg, 2000). The cost value in costeffectiveness study made for comparison of Clopidogrel and aspirin revealed that the cost for avoiding one stroke episode in secondary stroke prevention is approximately US\$ 33,000 with Clopidogrel, whereas calculated cost with aspirin is only US\$1,400 (Algra and Gijn, 2000).

Relative to the cost of using Clopidogrel and aspirin, an observation revealed that the price of Clopidogrel in Indonesia ranged from US $\$ 1.5$ to $\$ 3$ each tablet, higher than aspirin (ranged from 3.50 cent to 7.2 cent) of course, the cost of using Clopidogrel is higher and almost twice compared to aspirin. However, Clopidogrel is now included in the drug list which covered by government insurance (BPJS), so it will not too burden on the patients' own financial and this fact might have contributed to the increasing use of Clopidogrel in Indonesia. In Indonesia Clopidogrel usage as an antithrombotic in each hospital has reached 1000 tablets per day, however aspirin is still higher than Clopidogrel, it has reached almost 1500 tablets per day.

\section{CONCLUSION}

Clopidogrel can be chosen in caring for cardiovascular disease especially in reducing the incidence of stroke, MI, or vascular disease.

\section{ANNEX}

1. How was the Clopidogrel discovered?

Clopidogrel discovery is clearly not by chance, and was discovered through rational pathway of research since there is understanding pathological pathway of acute cardiovascular disease (ACD). Clopidogrel is antiplatelet drug belongs to the class of thienopyridine. Ticlopidine is also a thyenopiriden member, but because of considerable side effect (neutropenia), Clopidogrel was developed with the aim of having a better effect with the lower drug toxicity. The chemical structure of Clopidogrel and ticlopidine is analogous.

2. What was the route of leading registration 
Prior to registration the drug had been assigned for a big clinical trial (CAPRIE) involving 19185 patients from 384 centres in 16 different countries in the world. Therefore the big phase III clinical study have been performed.

3. Are meta-analysis available?

Yes. Meta-analysis is available in the CAPRIE study and in the comparison of effectiveness study between Clopidogrel and ticlopidine.

4. Were studies on hard endpoints available?

Yes. The hard endpoint in Clopidogrel compared to aspirin is the composite endpoint of myocardial infarction, ischemic stroke and vascular death. This hard endpoint is the parameter measured in CAPRIE trial.

5. Were head to head comparison trial performed?

The data in head to head comparison is available in the comparison of Clopidogrel to aspirin in the CAPRIE trial. However, there is scarce information in the comparison of Clopidogrel to ticlopidine. The available data of comparion of Clopidogrel and ticlopidine is available through the meta-analysis study (Bhatt, Bertrand, Berger, 2002) involving 13, 955 patients. However by other author this comparison was criticized for the only 30 days of observation in the measurement of the hard endpoint (mortality)(Garattini and Bertele, 2004).

6. What happened after the drug on the market? Is it reimbursed?

Yes. Drug reimbursement by the Dutch government is already in 26 July 2000 . The reimbursement for Clopidogrel is applied for 6 months therapy. This limited time and strict regulation in Dutch government for the reimbursement of Clopidogrel is rational. Because there is limited advantages of using Clopidogrel over aspirin in the antiplatelet medication as proven by the CAPRIE trial, and the costeffectiveness still confirms that using aspirin is more cost effective than Clopidogrel. Moreover, through the safety and effectiveness study performed in
MATCH trial shows that combination of aspirin and Clopidogrel yielded a significant life threatening bleeding compared to monotherapy of Clopidogrel. In the MATCH trial showed also that effectiveness of combination aspirin and Clopidogrel compared to Clopidogrel is nonsignificant in reducing relative risk of the primary endpoint.

7. Which disease is targeted by the drug?

Clopidogrel is an antagonis of ADP receptor. The drug is targeted for the reduction of atheroschlerotic events including myocardial infarction, stroke, or peripheral artery disease, and is used in patients with non -ST segment elevation.

8. What is the impact of the drug compared to other drug?

In the area of antiplatelet therapy, aspirin remains the first line of therapy. Only for patient who shows intolerance to aspirin, Clopidogrel will be the given. Combination of aspirin and Clopidogrel is in the second line of therapy.

9 What is the information that still lacking?

The effectiveness study in CAPRIE trial challenges the conflicting interpretation from other investigators about the superiority of Clopidogrel to aspirin. Heterogenicity between subgroup in CAPRIE trial is thought to be favorable for the interpretation of the advantage therapy of Clopidogrel over aspirin (Garattini \& Bertele, 2004). Moreover, comparison study in meta-analysis between Clopidogrel and ticlopidine results in different interpretation. For 30 days therapy, Clopidogrel showed the significant benefit over ticlopidine in reducing mortality, however another investigator with longer investigation on Clopidogrel therapy (28 weeks) compared to ticlopidine showed that mortality is significantly higher in Clopidogrel treated group. Therefore, up to my understanding, the information that is still lacking is that the true conclusion whether Clopidogrel is only slightly advantage over aspirin or Clopidogrel provides a big significant benefit over aspirin and also ticlopidine. It might be 
useful to design the comparison of Clopidogrel and aspirin with avoiding such heterogenicity. Moreover, comparison study in Clopidogrel and ticlopidine is might be necessary in term of longer time of therapy.

\section{CONFLICT OF INTEREST}

The authors declare there is no financial interests either directly or indirectly associated with this manuscript.

\section{ACKNOWLEDGEMENT}

Many thanks to Stuned Foundation for the financial support and to Prof Dr M.J. Postma Departmen of Pharmaco-epidemiology and Pharmacoeconomics University of Groningen, Netherland, Dr Rustamaji M.Kes., Department of Pharmacology and Therapy, Universitas Gadjah Mada, for the guidance, inspirations, advices and as reviewer which made this study possible.

\section{REFERENCES}

Algra, A., Gijn, J.v., 2000. Is clopidogrel superior to aspirin in secondary prevention of vascular disease? Curr Control Trials Cardiovasc, 1, 143-145.

Amarenco, P., Donnan, G. A., 2004. Should the MATCH results be extrapolated to all stroke patients and affect ongoing trials evaluating clopidogrel plus aspirin? Stroke, 35(11), 2606-2608.

Aschenbrenner, D. S., Price, C., 2007. A new indication for clopidogrel. AJN, 107(2), 35.

Bertrand, M. E., Rupprecht, H.J., Urban, P., Gershlick, A. H., 2000. Double-blind study of the safety of clopidogrel with and without a loading dose in combination with aspirin compared with ticlopidine in combination with aspirin after coronary stenting. Circulation, 102, 624-629.

Bhatt, D., Marso, S., Hirsch, A., Ringleb, P.A., Hacke, W., Topol, E.J., 2002. Amplified benefit of clopidogrel versus aspirin in patients with diabetes mellitus. Am J Cardiol, 90, 625-628.
Bhatt, D. L., Bertrand, M. E., Berger, P.B., L'Allier, P.L., Moussa, I., Moses, J.W., Dangas, G., Taniuchi, M., Lasala, J.M., Holmes, D.R., Ellis, S.G., Topol, E.J., 2002. Meta-analysis of randomized and registry comparisons of ticlopidine with clopidogrel after stenting. J Am Coll Cardiol, 39(1), 9-14.

Braunwald, E., Antman, E. M., Beasly, J.W., Califf, R.M., Cheitlin, M.D., Hochman, J.S. et al., 2002. ACC/AHA Guideline Update for the Management of Patients With Unstable Angina and Non-STSegment Elevation Myocardial Infarction-2002; Summary Article: a report of the American College of Cardiology/American Heart Association Task Force on practice guidelines (Committee on the Management of Patients with Unstable Angina). Circulation, 106, 1893-1900.

Commitee, C. S., 1996. A randomised, blinded, trial of clopidogrel versus aspirin in patients at risk of ischaemic events (CAPRIE). Lancet, 348(9038), 1329-1339.

Diener, H. C., 2002. Aspirin therapy should be first-line treatment in secondary prevention of stroke--against. Stroke, 33(8), 2138-2139.

Donnan, G.A., Davis, S.M., 2002. Aspirin therapy should be first line: probably, but watch this space. Stroke, 33(8), 2139-2140.

Durand-Zaleski, I., Bertrand, M., 2004. The value of clopidogrel versus aspirin in reducing atherothrombotic events: the CAPRIE study. Pharmacoeconimic, 22(suppl 4), 19-27.

Garattini, S., Bertele, V., 2004. Risk: Benefit Assessment of Old Medicines. Br J Clin Pharmacol, 58(6), 581-586.

Gebel, J.M., Jr., 2005. Secondary stroke prevention with antiplatelet therapy with emphasis on the cardiac patient: a neurologist's view. J Am Coll Cardiol, 46(5), 752-755.

Hankey, G.J., 2005. Is clopidogrel the antiplatelet drug of choice for high-risk 
patients with stroke/TIA?: No. J Thromb Haemost, 3(6), 1137-1140.

Harker, L.A., Marzec, U.M., Kelly, A.B., Chronos, N.R., Sundell, I.B., Hanson, S.R., et al., 1998. Clopidogrel inhibition of stent, graft, and vascular thrombogenesis with antithrombotic enhancement by aspirin in nonhuman primates. Circulation, 98, 2461-2469.

Herbert, J.M., Dol, F., Bernart, A., Falotico, R., Lale, A., Savi, P., 1998. The antiaggregating and antithrombotic activity of clopidogrel is potentiated by aspirin in several experimental models in the rabbit. Thromb Haemost, 80, 512518.

Herbert, J., Tissinier, A., Defreyn, G., Maffrand, J., 1993. Inhibitory effect of clopidogrel on platelet adhesion and intimal proliferation following arterial injury in rabbits. Arterioscler Thromb, 13, 1171-1179.

Makkar, R., Eigler, N., Kaul, S., Frimerman, A., Nakamura, M., Shah, P., et al., 1998. Effects of clopidogrel, aspirin and combined therapy in a porcine ex vivo model of high-shear induced stent thrombosis. European Heart Journal, 19, 1538-1546.

Mueller, C., Roskamm, H., Neumann, F.J., Hunziker, P., Marsch, S., Perruchoud, A., et al. 2003. A randomized comparison of clopidogrel and aspirin versus ticlopidine and aspirin after the placement of coronary artery stents. Journal of the American College of Cardiology, 41(6), 969-973.

NHS, 2004. Clopidogrel in the treatment of non-ST-segment-elevation acute coronary syndrome Technology Appraisal 80. National Institute for Clinical Excellence, 1-24.
Niessen L.W., Dippel, D.W., Limburg, M., 2000. Calculation of costs of stroke, cost effectiveness of stroke units and secondary prevention in patients after a stroke, as recommended by revised CBO practice guideline 'Stroke'. Ned Tijdschr Geneeskd, 144(41 abstract), 1959-1964.

Philips, D.R., Conley, P.B., Sinha, U., Andre, P., 2005. Therapeutic approaches in arterial thrombosis. J.of throm \& Haem, 3, 1577-1589.

Ringleb, P.A., Bhatt, D.L., Hirsch, A., Topol, E.J., Hacke, W., et al, 2004. Benefit of clopidogrel over aspirin is amplified in patients with a history of ischemic events. Stroke, 35, 528-532.

Sado, D., 2001. Drug Discovery. Student BMJ, $3,13-15$

Sharis, P., Cannon, C., Loscalzo, J., 1998. The antiplatelet effects of ticlopidine and clopidogrel. Ann Intern Med, 129, 394405.

Steinhubl, S.R., Tan, W.A., Foody, J. M., Topol, E.J., 1999. Incidence and clinical course of thrombotic thrombocytopenic purpurea due to ticlopidine following coronary stenting. JAMA, 281(9), 806810.

Tran, H., Anand, S.S., 2004. Oral Antiplatelet Therapy in Cerebrovascular Disease, Coronary Artery Disease, and Peripheral Arterial Disease. JAMA, 292(15), 18671874.

Warlow, C., 2002. Aspirin should be first-line antiplatelet therapy in the secondary prevention of stroke. Stroke, 33(8), 2137-2138.

Weitz, J., Hirsh, J., 1998. New antothrombotic agents. Chest, 114(5), 715S-727S.

Yeghiazarians, Y., Braunstein, J., Askari, A., Stone, P., 2000. Unstable angina pectoris. N Engl J Med, 342, 101-114. 